\title{
Europe: Dream of Unity, Reality of Divisions
}

\author{
Aleš Debeljak
}

In the 1990s, the European Union aimed to achieve two ambitious goals: to end the wars for Yugoslav succession and to lead the nations of former communist countries in Eastern Europe toward economic and social prosperity. Both of these goals remain elusive. The Dayton Accord, brokered by the United States in 1995, merely "froze" the state of war on the territory of former Yugoslavia without remedying its causes. Moreover, it was not a European, but an American military force that effectively intervened in Bosnia and then later in Kosovo. Indeed, only with a very slight exaggeration do I say that Sarajevo would still be under siege today if the Yugoslav wars had remained the exclusive responsibility of the EU.

As for the second goal, the economic and social prosperity for post-communists countries, it is undeniable that the "velvet revolutions" of 1989 ushered in a period of renewed hope. Yet, the EU failed to respond with its version of the Marshall Plan, offering substantial and comprehensive assistance to these nations. The subsequent integration of many of these countries into the EU presents a grave political, cultural and economical challenge. To put it bluntly: the mission of the EU to bring prosperity and stability into Eastern Europe and the Balkans is an expensive and contradictory enterprise. It is sure to keep the EU nations at odds for at least several generations to come. We are thus left with the dawning realization that Europeans may have tragically failed in the very objectives that they strove to realize on their own, that is, without outside (read: American) help.

From this angle, it seems all the more clear that the various channels connecting Europe and America reflect a real, mutual, and inescapable dependence. Suffice to point out the trade networks between the EU and the US, the density of which is only surpassed by the commercial traffic within EU (that is, among the EU members themselves). Despite the messianic self-righteousness of the American government under president George W. Bush and the ill-justified occupation of Iraq in the spring of 2003, the community of European nations cannot simply retreat into their historical bunker of cultural specificities and try to define itself against America. The attempt to build a European political identity on anti-American foundations is, I fear, just as likely to fail as the past attempt of German Romantics to define their nation on an exclusively anti-French basis.

In addition, America has been much more systematic in providing support to Eastern European anti-communist dissidents and the fresh buds of civil society that sprouted there. From a historical vantage point, this is hardly a surprise. In the wake of World War II, Western Europe was a de facto American military protectorate. It is ironic that without the threat of war and the American assistance to avert it, Europeans would certainly not have been able to afford the massive investment, over half a century, into their search for "universal peace". It was only under the protective umbrella of NATO with America at its helm, that Western Europe could begin the post-war project of reconciliation and integration.

During these years, Europe took ample advantage of the American aid intended to rebuild the destroyed continent. America provided European nations with the initial incentive to summon adequate political will to overcome the violent conflicts that had divided them for centuries. This endeavor required the strategic construction of common life-world structures that were meant to render war between European nations not only materially impractical, but also morally unacceptable and politically unfathomable. Despite progress in this direction, however, it has not been possible for Europe to entirely eliminate obstacles on the complex map of historical hostilities, across 
which any idea of a community of European nations must navigate.

To conceive of Europe's imaginary totality was to draw identifiable boundaries. But the absence of a strict natural border on the eastern flank of the continent has, instead, conditioned the need for a symbolic geography. Distinct areas were and continue to be defined by mutual opposition. In other words, Europe has traditionally defined itself negatively, its self-perception arising from what it is not, rather than from what it is. Accordingly, Europe's outer boundaries shifted with political circumstances and contingent features of different social-historical periods. At various times, this boundary has been determined by the Oder and Neisse rivers, by the ridges of the Carpathian Mountains, the Ural Mountains, the summits of the Alps and the Pyrenees, the Atlas mountains, the coasts of the Black and Caspian Seas, the Iron curtain, and, most recently, by the Schengen limes. Throughout the ongoing changes in the meaning that Europe has attributed to the imagined or real enemy, temporary alliances of interest and pragmatic coalitions of power were formed.

The smallest common denominator in a communal integration was fear. In the collective mind of the nations claiming membership in Europe, the West and the East have acquired polarized values. In modern times, it was Eastern Europe and the Balkans with the attendant communist ideology that assumed this negative role. In the Middle Ages, European rhetoric has persistently perceived Islamic culture as the "Other" in its ongoing process of defining borders between the domestic and foreign, between us and them. After New York and Washington's 9/11, Madrid's 3/11 and London's 7/7, it seems, the image of Islam as "the Other", as the threat, was revived in a European public discourse.

The noble ambition that wants to see Europe united and free has since World War II inspired a significant part of the national elites. These elites realized that they must limit the potential sources of fear, while at the same time striving to integrate diverse ethnic, cultural and social traditions into common structures. This ambition continues to drive many European leaders.

But where does Europe end? And who, really, is European? Will we, the citizens of post-communist countries, new members of the EU after May 2004, receive not only the political rights of European citizenship, but also the societal respect worthy of an association of equals? How long will it take to cast off the legacy of the traditionally divided continent? How long will Western Europeans need to overcome the deep-rooted feelings of suspicion (or at best apathy) that they feel toward the "barbaric" states and peoples of the East, Europe's terra incognita? How long will East Europeans behave like poor little relatives trying to impress? I wish I knew.

Sure, for some commentators the very idea of a united Europe provokes a condescending smile, but if history can possibly be of any use, than we could do worse than assimilate a lesson that it is equally laughable to contemplate a divided and, at the same time, successful Europe. A united Europe, of course, would be utterly unique. To the extent that the European Union does have many features of the state, it is a state of nations and not a nation of states like United States of America. The EU is thus inventing a self-suitable political form as it goes along. The dream of a united Europe, however, is ancient. It was pursued by the Roman Empire, Charlemagne and Napoleon, but also by Hitler (and this is only a partial list). After World War II, the European idea was adopted by the institutions that were conceived to prevent future armed conflict on the continent. Regardless of the vantage point, one is left with the same conclusion: the European idea is indelibly scarred by wars, aggression and violent conflict.

In order for European citizens to gain a reflexive awareness of our shared history, the shaping of the politics of European identity is of paramount importance. Yet sober reflection calls for humility. The face of "Europeanness" is invisible. Distinctly European elements of one's identity are today not easy to pinpoint. Moreover, in order to have a vision for a progressive realization of European identity, the common goals of European integration would have to be defined if they are to serve as guidelines. In view of the bickering inside the EU and the bitter disputes over the European constitution, alas, it is impossible to deduce with any certainty what are in fact the common goals of European integration. Does the goal lie in a particular vision of "Fortress Europe" which should close its doors to new members after the Balkan "rhythm \&amp; blues", Bolgaria and Romania, entered the club? Or is the goal projected in Europe as the embodiment of universal ideas: the rule of law, the liberal democratic system, constitutional respect for human rights? A union that can and must expand, perhaps to Turkey and the southern coasts of the Mediterranean, if not to the countries lying east of Polish borders?

In an unstable environment of post-Cold War, the European Union appears to be perceived, at least among the elites and middle classes in the continent's eastern part, as the ultimate purpose of national life. This large segment of the public that pins their hopes for quick improvement of living conditions on decidedly West European standards, may choose to conveniently look the other way -- but one fact won't disappear: despite the collapse of communism Western Europe remains by and large a "family onto itself". 
Observed from this perspective, four aspects in the genesis of contemporary Europe come to the fore. First, there is the economistic ideology that emerged from etatist political culture, based as it is on the belief that it is possible in a relatively short time to change individual behavior and values by changing market conditions. The second aspect lies in the fact that Europe defines itself negatively, as indicated above. The third aspect is the shared mental framework that might eventually nurture the commonality of European nations. At present, this frame is still weak, abstract and optional. The "European joke" is a case in point: there are virtually no jokes about Europeans, in contrast to the cornucopia of jokes about individual nations. As stereotype-affirming as jokes tend to be, they do reveal the preoccupations of ordinary people in their everyday lives. A European is featured as neither the protagonist nor the butt of jokes for the simple reason that "Europeanism", the nascent identity in which to ground such a subject, is hardly present in public spheres of individual nation-states.

This brings us to the fourth key aspect of the current European order: its democratic deficit. United Europe remains the project of social elites rather than that of broader national constituencies. Due to the inescapable fact that the European Union is being established from the top down, it has yet to take full root among ordinary people. The European anthem, the flag, and the Euro banknotes are isolated bricks in the mental structure of the European identity; they still need ligatures to hold them together.

The enlarged EU, which lives on formal procedures, negotiation, and consensual compromise in the search of the common good, faces its most profound challenge: it must invent a new political design. Regardless of whether the future holds prospects for a confederate Europe or for a federation, a European democratic political culture must first be put in place and developed within member-states themselves. This is especially true in the post-communist countries where democracy barely entered its early adolescence. Democratic life in individual member-states is thus the main precondition for fostering the democratic habits on a transnational European level.

Unfortunately, a culture with trust, consent, and solidarity as the main ingredients in a common European life remains a long way off. From the vantage point of Eastern European experience, it is difficult to not see a Medusa of "traditional West" rearing its compromised head in a political ambition of some of the most prominent contemporary intellectuals, including Jurgen Habermas and Jacques Derrida. The idea of a pragmatically justified KernEuropa that would lead the European Union with relative independence from the anguished and, no doubt, cumbersome process of decision-making by consensus in an enlarged EU, this idea gives a dangerous credence to perhaps inevitable, but emphatically non-democratic concept: Europe of two speeds, Europe of the first- and second-class citizens. I am afraid that this trend only reinforces the historical discrimination of the traditional West against the countries, languages, cultural traditions, and people in the "Wild East", les petit pays de merde, as some French diplomats are wont on saying.

The fact that, while Europe fidgeted, America finally intervened with military force in Bosnia and Kosovo (however late) complicates my personal dilemma all the more. My dilemma grows, in part, from the realization that many rejections of the American strategic dominion in Europe are permeated with an anti-American sentiment. It is this popular sentiment that has, after the end of the Cold War, replaced the structural source of fear that the Soviet Empire once represented. I would be blind, though, if I didn't recognize something else, too. The escalation of America's global military presence that began with the legitimate and internationally legal attack on Afghanistan and went on to occupy Iraq without broad international consensus, has meant a huge backward step for transatlantic and international relations. Conceived on spurious grounds if not outright straight-face lies, it drove a wedge in the Western alliance. In fact, the "coalition of the willing" might properly be called a "coalition of the deceived", as the supporting states were twisted into believing in the existence of Iraqi weapons of mass destruction.

The legacy of American ties to Europe, however, cannot be regarded in the contemporary context alone. A united and free Western Europe was, for Americans, the best form of security and peace. Over the course of the last hundred years, Europe produced two World Wars, was the key geographical and political stage of the third, the Cold War, and then failed to decisively intervene in the wars in its backyard, former Yugoslavia. Each of these conflicts prompted in turn an American engagement on the European continent.

After the Cold War, America gradually ceased being seen as the exclusive guardian of the old continent. Instead, it became a mirror that Europe uses to correct and improve its self-image. At the same time, American strategic interest in European affairs has declined and America has begun to shift its focus to the former Soviet Central Asia and the Arab peninsula. Later, America would be naively appalled when faced with the fact that most of the European countries refused to join the United States in its dangerous Iraqi adventure. The American Secretary of Defense's notorious division of countries according to the attitude toward the invasion of Iraq into "the Old Europe" and the "new Europe" had a twofold character. On the one hand, it reveals a policy of "divide and conquer" that benefits 
America. On the other, it has functioned as a sobering statement that may one day work to Europe's benefit. The division clearly illustrated at least the following: first, the governments of post-communist countries who have been practically given an ultimatum as to the adoption of acquis communautaire, without the chance to actively participate in a debate in all but the very last stages of enlargement process, now demand the right to have a voice in the common European house. Second, these governments and their publics have not forgotten the Cold War. It was during this period that a culture of mutual trust and solidarity between the Western and Eastern Europe lived a miserable existence, to put it euphemistically.

In order for Europe to achieve solid legitimacy as a pluralistic "open society", it must therefore significantly enhance the culture of trust. The culture of trust presupposes a democratic frame defined by solidarity. As with many other underlying social concepts, however, Western and Eastern Europe differ in their concept of the basic social bond. In the modern Western world, the understanding of solidarity is pragmatic while in the East, the understanding of solidarity has been a moral one. Typical of the former is a concerted effort to join forces of all involved in order to attain a common goal which in turn reflects the common values and interests of participants. In the East, the prevailing belief is that solidarity is rooted in the imperative of unselfish assistance: the stronger offers to the weaker, even if the only reward is a feeling of moral satisfaction.

There is no doubt that institutionalized solidarity played a key role in contributing to the modernization of Greece, Ireland, Spain, and Portugal following their entry into the common European structures. Solidarity, alas, was since forced to yield to the demands of greater individual freedom and economic profits that have grown apace with global capitalism. The rebellion of the middle class against the continuation of guarantees for the social safety nets has been in Western Europe politically channeled into restrictions on the national budgets. The result? Solidarity, once the central pillar of social order, is now seen as a luxury which individual nations can, but are not obliged to, afford. It is no longer a crucial value. Instead, it has been pushed off to the sidelines.

Those, however, who reject the necessity of solidarity's handshake and prefer to swear by the hidden hand of the market, must remain blind to what shape would this hand assume should it be visible: a fist with a pointed middle finger. Until it becomes a mind-set of common belonging for people across European lands, without two-class discrimination among them, united Europe will remain what it is today: a noble dream. 